Prepared in cooperation with the California State Water Resources Control Board

\title{
Multiple-Well Monitoring Site Adjacent to the North and South Belridge Oil Fields, Kern County, California
}

Any use of trade, firm, or product names is for descriptive purposes only and does not imply endorsement by the U.S. Government.

The U.S. Geological Survey (USGS), in cooperation with the California State Water Resources Control Board, is evaluating several questions about oil and gas development and groundwater resources in California, including (1) the location of groundwater resources; (2) the proximity of oil and gas operations to groundwater and the geologic materials between them; (3) evidence (or no evidence) of fluids from oil and gas sources in groundwater; and (4) the pathways or processes responsible when fluids from oil and gas sources are present in groundwater (U.S. Geological Survey, 2017). As part of this evaluation, the USGS installed a multiple-well monitoring site in the southern San Joaquin Valley groundwater basin adjacent to the North and South Belridge oil fields, about 7 miles southwest of Lost Hills, California (fig. 1). Data collected at the Belridge multiple-well monitoring site (BWSD) provide information about the geology, hydrology, geophysical properties, and geochemistry of the aquifer system, thus enhancing understanding of relations between adjacent groundwater and the North and South Belridge oil fields in an area where there are few groundwater data. This report presents construction information for the BWSD and initial hydrogeologic data collected from the site. A similar site installed to the east of the Lost Hills oil field, 11.5 miles to the north of the BWSD site, was described by Everett and others (2020a).

\section{Study Area}

The Belridge multiple-well monitoring site (BWSD) is in the Kern County subbasin of the San Joaquin Valley groundwater basin situated on the southern end of the Tulare Lake Hydrologic Region (California Department of Water Resources, 2016; fig. 1). The BWSD is located due east of the administrative boundary between the North and South Belridge oil and gas fields; approximately 7,000 feet (ft; 1.3 miles [mi]) east and downgradient (Williamson and others, 1989) from the northeast corner of the South Belridge field.

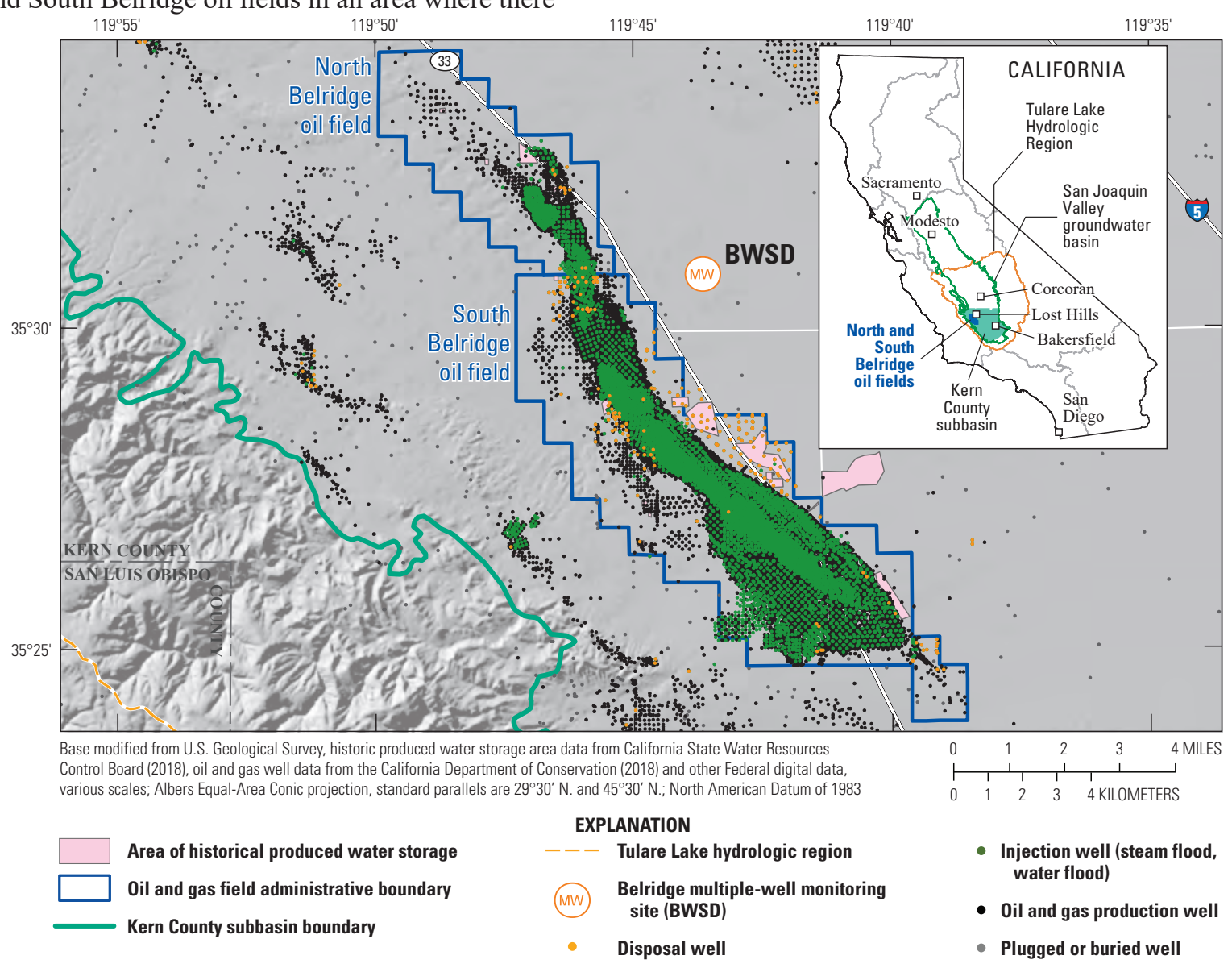

Figure 1. Belridge multiple-well monitoring site (BWSD) and selected other wells in relation to the North and South Belridge oil fields, Kern County, California. 
The primary water-bearing units on the west side of the Tulare Lake Hydrologic Region lie within the Pliocene- to Pleistocene-age Tulare Formation, the overlying Holocene-age older alluvium and terrace deposits, and recent alluvial and river sediments (California Department of Water Resources, 2015). The Tulare aquifer system comprises the water-bearing units within the Tulare Formation that are separated locally and regionally by confining units. The alluvial aquifer system, comprised of the sediments overlying the Tulare Formation, is a complex set of interbedded aquifers and aquitards that function regionally as a single water-yielding unit (Sneed, 2001). Numerous lenses of fine-grained sediments are distributed throughout the San Joaquin Valley; these generally constitute more than 50 percent of the total thickness of the valley fill (Faunt, 2009). Faunt (2009) also noted that sediments in the western part of the San Joaquin Valley generally are finer-grained than sediments located to the east.

The primary confining unit of the Tulare Lake Hydrologic Region is the Corcoran Clay (Frink and Kues, 1954) and its equivalent, the E-clay of Croft (1972). For the purposes of this discussion, the Corcoran Clay and the E-Clay are simply referred to as the Corcoran Clay. The Corcoran Clay underlies approximately the western two thirds of the San Joaquin Valley extending from the southern edge of the valley, near Kern Lake (not shown), to north of Modesto (Faunt, 2009). The Corcoran Clay is thicker in an area between Lost Hills and Corcoran, located about $35 \mathrm{mi}$ to the north, and may be as thick as $200 \mathrm{ft}$ approximately $14 \mathrm{mi}$ north of Lost Hills (Faunt, 2009). Petroleum companies operating in the area refer to a basal alluvial clay at the contact between the Tulare Formation and overlying alluvium as the Corcoran Clay equivalent (Gilespie and others, 2019a). The exact relation between the Corcoran Clay equivalent and the Corcoran Clay is not defined; therefore, for the purposes of this report the clay at the BWSD site will be termed the Corcoran Clay equivalent and is presumed to be the lateral equivalent of the Corcoran Clay. At the BWSD, the top of the Corcoran Clay equivalent is determined to be 284 feet below land surface (ft bls), and the clay is $42-\mathrm{ft}$ thick.
Locally, Faunt (2009) showed the western edge of the clay generally is coincident with the eastern edge of the South Belridge oil field administrative boundary whereas Gillespie and others (2019a) mapped the Corcoran Clay equivalent farther west into the field and suggested the extent is closer to the western edge of the South Belridge oil field administrative boundary. The confining clay layers and land surface slope downward gradually from the North and South Belridge oil fields toward the BWSD borehole (Gillespie and others, 2019a).

The BWSD location was selected to provide better information regarding vertical and lateral changes in groundwater gradients and water quality of the alluvial and Tulare aquifer system. The site is situated east of the North and South Belridge oil fields and downgradient from these intensively developed oil fields where the detection of oil-field fluids in overlying and adjacent groundwater zones, when present, could exist from (1) naturally existing oil and gas in aquifers in proximity to oil fields or (2) a range of historical and current oil and gas development activities. There are a number of activities in developed oil fields that could affect groundwater including surface spills, leakage of produced water from disposal ponds, injection of fluids into the subsurface for enhanced recovery and produced-water disposal, and potential introduction of preferential pathways such as leaky or improperly abandoned oil and gas wells or test holes (Davis and others, 2018a; Gillespie and others, 2019a).

There is a high concentration of oil-production activities near the BWSD. The BWSD is approximately $1,400 \mathrm{ft}$ from the nearest idle well, 7,100 ft from the nearest water disposal well, 7,300 ft from the nearest active oil well, 8,200 ft from the nearest active steam flood well (injection of steam for enhanced recovery of oil), and 10,000 ft from the nearest water flood well. Activities within 2 mi to the south and west of the BWSD include 512 wells that are plugged or buried; 194 steam-flood wells, 108 oilor gas-production wells that are active, inactive, or new; 16 water-flood wells that are active, inactive, or new; 13 water-disposal wells, and 1 area where produced water-storage ponds have been or are currently located (California Department of Conservation, 2018).

\section{Drilling and Well Installation}

The BWSD pilot borehole, with a diameter ranging from $81 / 2$ to $7 \frac{5}{8}$ inches, was drilled to a depth of 1,800 ft bls during July 2018 by using direct mud-rotary drilling. Drill cuttings were collected throughout the drilling process and analyzed (along with notes from the on-site geologist) to summarize the lithology (fig. 2) following the procedures described by Everett and others (2013). To assist in the identification of lithologic and stratigraphic units, geophysical logging of the borehole was completed using standard methods (Keys and MacCary, 1971; Shuter and Teasdale, 1989; Keys, 1990; Kenyon and others, 1995). Geophysical logs completed at the site include caliper, natural gamma, resistivity (16- and 64-inch normal), spontaneous potential (SP), electromagnetic induction, temperature, full wave sonic (sonic porosity), and nuclear magnetic resonance (NMR) porosity (fig. 2). Logging in the small-diameter pilot hole was advantageous because it allowed for higher-quality logs to be collected compared to logs from larger diameter holes. Well-screen and filter-pack intervals were selected based on the geophysical and lithologic data. After these intervals were selected, the pilot hole was then reamed to increase the borehole diameter to allow for the construction of the five-well monitoring site. The deepest well (BWSD \#1) was constructed with 2.5-inch-diameter polyvinyl chloride (PVC) casing to allow for future geophysical logging, and the four shallow wells were constructed with 2-inch-diameter PVC casing. The wells were installed with screened intervals from 260 to 280 (BWSD \#5); 510 to 530 (BWSD \#4); 870 to 890 (BWSD \#3); 1,170 to 1,190 (BWSD \#2); and 1,495 to 1,515 (BWSD \#1) ft bls (table 1). A filter pack of \#3 sand (granules) was installed around each well screen, and a low-permeability bentonite grout was placed in the depth intervals between the filter packs to seal/isolate each of the wells (fig. 2). 


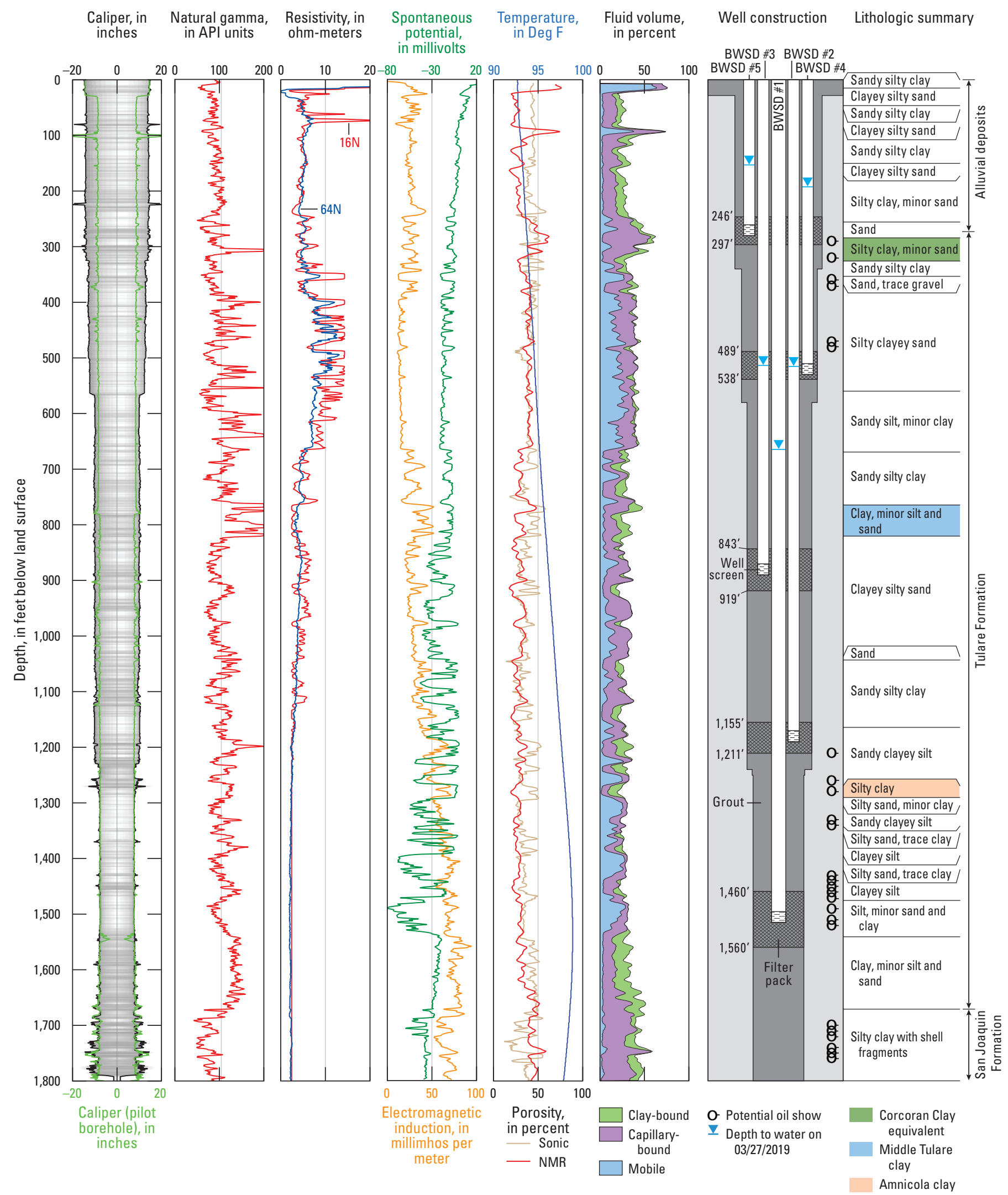

Figure 2. Well construction, summary lithology, and geophysical log data from the Belridge multiple-well monitoring site (BWSD), Kern County, California. (Abbreviations: API, American Petroleum Institute units; 16N, 16-inch normal; 64N, 64-inch normal; Deg, degrees; F, Fahrenheit; NMR, nuclear magnetic resonance). 
Table 1. Identification and construction information from the Belridge multiple-well monitoring site (BWSD), Kern County, California.

[See figure 1 for well locations. Wells ordered from shallowest to deepest. The 15-digit U.S. Geological Survey (USGS) site identification number is used to uniquely identify the well. The common name is used throughout the report for quick reference. Land-surface datum (LSD) is a datum plane that is approximately at land surface at each well. The elevation of the LSD is described in feet above the North American Vertical Datum of 1988 (NAVD88). Abbreviations: NWISWeb, National Water Information System web interface; $\mathrm{ft}$ bls, feet below land surface]

\begin{tabular}{ccccccc}
\hline $\begin{array}{c}\text { Common } \\
\text { well } \\
\text { name }\end{array}$ & $\begin{array}{c}\text { USGS site } \\
\text { identification } \\
\text { number (hyperlinked } \\
\text { to NWISWeb) }\end{array}$ & $\begin{array}{c}\text { Elevation } \\
\text { of LSD } \\
\text { (ft above } \\
\text { NAVD88) }\end{array}$ & $\begin{array}{c}\text { Well } \\
\text { diameter } \\
\text { (inside, } \\
\text { inches) }\end{array}$ & $\begin{array}{c}\text { Depth to } \\
\text { bottom of } \\
\text { well } \\
\text { (ft bls) }\end{array}$ & $\begin{array}{c}\text { Depth to of well } \\
\text { top } \\
\text { screen } \\
\text { (ft bls) }\end{array}$ & $\begin{array}{c}\text { Depth to } \\
\text { bottom of } \\
\text { well screen } \\
\text { (ft bls) }\end{array}$ \\
\hline BWSD \#5 & 353049119434105 & 492.03 & 1.94 & 280 & 260 & 280 \\
BWSD \#4 & 353049119434104 & 492.03 & 1.94 & 530 & 510 & 530 \\
BWSD \#3 & 353049119434103 & 492.03 & 1.94 & 890 & 870 & 890 \\
BWSD \#2 & 353049119434102 & 492.03 & 1.94 & 1,190 & 1,170 & 1,190 \\
BWSD \#1 & 353049119434101 & 492.03 & 2.32 & 1,515 & 1,495 & 1,515 \\
\hline
\end{tabular}

After construction was completed, the wells were developed by airlifting and using a surging technique with compressed air to remove drilling fluid and develop the filter pack surrounding each monitoring well. The field parameters that were recorded during the process include specific conductance, $\mathrm{pH}$, water temperature, apparent color, and turbidity. Well development continued until drilling mud was not evident and field parameters were stabilized. The average flow rate and development time was used to estimate the total discharge and total purge volumes of the casing and filter pack (table 2). After well development, the turbidity of all wells was equal to or below 10 nephelometric turbidity units (NTU; table 2).

\section{Sediment Analysis}

The lithology at the site consists of gravel, sand, silt, and clay (fig. 2) in overlying alluvial deposits and the Tulare Formation and marine silts and clays of the underlying San Joaquin Formation. is fine-grained and is consistent with observations by Page (1983) that the Tulare Formation along the western edge of the southern San Joaquin Valley is fine grained, particularly at depth. The contact between the alluvial deposits and the Tulare Formation is estimated to be at $273 \mathrm{ft}$ bls based on changes in color of the sediment from light yellowish brown to olive gray and an abrupt change in the SP log; however, as noted by Wood and Davis (1959), it is difficult to distinguish The lithology at this location primarily the alluvial deposits from the upper Tulare Formation in this region. The depths to the top and bottom contacts of several prominent clay layers within the Tulare Formation observed at BWSD are more apparent based on characteristic shifts in borehole geophysical logs observed across the area (Gillespie and others, 2019a) and are identified as Corcoran Clay equivalent, 284-326 ft bls; middle Tulare clay, $764-820 \mathrm{ft}$ bls; and Amnicola clay, 1,269-1,290 ft bls. The base of the Tulare Formation is estimated at 1,671 ft bls based on borehole log interpretation (Gillespie and others, 2019a).

Shell fragments were observed at several depths below $1,700 \mathrm{ft}$ bls (fig. 2). Shell fragments observed at about $1,715 \mathrm{ft}$ bls were identified simply as "molluscan." Trace amounts of shell fragments less than 2 millimeters in size observed below 1,760 ft bls were not identified.

Hydrocarbon fluorescence under ultraviolet light can indicate the presence of oil in small amounts. The most reliable test for hydrocarbons in drill cuttings is the cut fluorescence, or wet cut test, which utilizes an organic solvent to dissolve the oil and observing the fluorescence of the resulting cut (Swanson, 1981). Samples collected every 10 feet were lightly rinsed in acetone and then inspected under a black light for fluorescence (Wyman and Castano, 1974; Swanson, 1981). The presence of any fluorescence was noted as a potential oil show (fig. 2).

Table 2. Well development and water-level data from the Belridge multiple-well monitoring site (BWSD), Kern County, California.

[Wells ordered from shallowest to deepest. Abbreviations: ft bls, feet below land surface; gal/min, gallons per minute; gal, gallon; v/v, volume per volume; NTU, nephelometric turbidity units]

\begin{tabular}{|c|c|c|c|c|c|c|c|c|c|}
\hline $\begin{array}{l}\text { Common } \\
\text { well name }\end{array}$ & $\begin{array}{l}\text { Pre-development } \\
\text { depth to water } \\
\text { (ft bls) }\end{array}$ & $\begin{array}{c}\text { Post-development } \\
\text { depth to water } \\
\text { (ft bls) } \\
\text { (Nov. 20, 2018) }\end{array}$ & $\begin{array}{l}\text { Depth to water } \\
\text { (ft bls) } \\
\text { (Mar. 27, 2019) }\end{array}$ & $\begin{array}{l}\text { Average } \\
\text { flow } \\
\text { (gal/min) }\end{array}$ & $\begin{array}{l}\text { Hours of } \\
\text { develop- } \\
\text { ment }\end{array}$ & $\begin{array}{l}\text { Estimated } \\
\text { total } \\
\text { discharge } \\
\text { (gal) }\end{array}$ & $\begin{array}{l}\text { Purge per } \\
\text { casing } \\
\text { volume } \\
\text { (v/v) }\end{array}$ & $\begin{array}{c}\text { Purge per } \\
\text { sand pack } \\
\text { volume } \\
\text { (v/v) }\end{array}$ & $\begin{array}{l}\text { Post- } \\
\text { development } \\
\text { turbidity } \\
\text { (NTU) }\end{array}$ \\
\hline BWSD \#5 & $158.46^{*}$ & 158.36 & 157.88 & 5.0 & 24 & 6,700 & 345 & 31 & 7 \\
\hline BWSD \#4 & $193.79 *$ & 192.14 & 191.15 & 5.0 & 16 & 4,600 & 86 & 21 & 7 \\
\hline BWSD \#3 & $513.87 *$ & $513.68^{*}$ & 513.89 & 3.2 & 33.5 & 4,600 & 76 & 24 & 4 \\
\hline BWSD \#2 & $514.59^{*}$ & 514.91 & 514.88 & 3.3 & 14 & 2,900 & 27 & 16 & 3 \\
\hline BWSD \#1 & $659.40 *$ & 662.41 & 663.13 & 8.0 & 48 & 16,900 & 79 & 94 & 10 \\
\hline
\end{tabular}

*Value from Everett and others, 2020b. 


\section{Hydrology}

\section{Aquifer Tests}

The hydraulic conductivity (K) of the aquifer material adjacent to the screened interval was estimated from pneumatic slug tests completed on each of the wells. Compressed nitrogen gas was used to depress the water level in the well by using a pressure regulator and well-head apparatus following procedures similar to Leap (1984) and Greene and Shapiro (1995). Induced declines in water levels were hundreds of feet above the perforations so that no nitrogen gas entered the formation through the well screen. Multiple slug tests were completed in each well except for well $\# 3$, and average values are shown in table 3. Aquifer properties analysis was completed using AQTESOLV software (Duffield, 2007). Data from BWSD $\# 1$, \#2, and \#5 were analyzed using the Kansas Geological Survey (KGS) Model package for overdamped slug tests in partially penetrating wells in a confined aquifer (Hyder and others, 1994). Data from BWSD \#4 were analyzed using the Butler-Zhan solution which allows for the analysis of an underdamped response (Butler and Zhan, 2004). Data from BWSD \#3 were not analyzed because the well may not have been fully developed at the time of testing. Slug test data are available in Everett and others (2020b).

Hydraulic conductivity estimates ranged from 1 foot per day (ft/day) in BWSD \#5 to $17 \mathrm{ft} /$ day in BWSD \#4 (table 3; Everett and others, 2020b). These values were in the range of values expected for sand with gravel, silt, and clay, although the value at BWSD \#5 of $1 \mathrm{ft} /$ day was at the low end of typical values (Heath, 1983). Belridge multiple-well monitoring site BWSD \#5 is completed in a thin sand layer below a silty clay and is just above the Corcoran Clay equivalent. The presence of fine-grained sediments in the sand layer that were not observed in the drill cuttings could account for the low hydraulic conductivity.

\section{Water Levels}

Water-level data collected included periodic discrete manual measurements and hourly data recorded by downhole pressure transducers. Methods described by Cunningham and Schalk (2011) were used to collect and quality-assure the water-level records. The data were analyzed to identify vertical water-level gradients, which indicate direction and variability of potential groundwater flow between aquifer layers and responses to factors such as recharge and local groundwater withdrawal.

Before installation of the BWSD, there were no available data on vertical profiles of groundwater flow across the full thickness of the alluvial and Tulare aquifer systems near the North and South Belridge oil fields. The vertical water-level gradients at the site calculated from multiple discrete water-level measurements collected on March 27, 2019 (fig. 3; table 2), indicated that

Table 3. Summary results of slug tests from the Belridge multiple-well monitoring site (BWSD), Kern County, California.

[Wells ordered from shallowest to deepest. Abbreviations: ft bls, feet below land surface; ft/day, feet per day; KGS, Kansas Geological Survey; NA, not analyzed]

\begin{tabular}{cccc}
\hline $\begin{array}{c}\text { Common } \\
\text { well name }\end{array}$ & $\begin{array}{c}\text { Screened interval } \\
\text { (ft bls) }\end{array}$ & $\begin{array}{c}\text { Method of } \\
\text { analysis }\end{array}$ & $\begin{array}{c}\text { Hydraulic } \\
\text { conductivity } \\
\text { (ft/day) }\end{array}$ \\
\hline BWSD \#5 & $260-280$ & KGS model & 1 \\
BWSD \#4 & $510-530$ & Butler-Zhan & 17 \\
BWSD \#3 & $870-890$ & NA & NA \\
BWSD \#2 & $1,170-1,190$ & KGS model & 2 \\
BWSD \#1 & $1,495-1,515$ & KGS model & 3 \\
\hline
\end{tabular}

groundwater should flow downward through the Tulare aquifer system. The groundwater gradient was highest, -0.897 foot per foot $(\mathrm{ft} / \mathrm{ft})$, between BWSD \#4 and BWSD \#3 and lowest, $-0.003 \mathrm{ft} /$ $\mathrm{ft}$, between BWSD \#3 and BWSD \#2. The steep gradient between BWSD \#4 and BWSD \#3 indicated that the middle Tulare clay, which separates these two wells, is an effective aquitard separating overlying and underlying aquifer layers at this location.

Water-level changes that happened over time were used to help determine the degree of hydraulic interaction between aquifer layers that are restricted by confining clay layers. The change in water level for each well relative to November 20, 2018, at 4:00 p.m. Pacific daylight time (PDT) was calculated (fig. 4; BWSD \#3 had no data for that date and time but was estimated to be $513.83 \mathrm{ft}$ bls based on the average difference in water level from BWSD \#2). During the period between November 20, 2018, and September 6, 2019, a water-level rise of 2.5 feet was observed in BWSD \#4, and a decline of about 3.75 feet was observed in BWSD $\# 1$, the deepest well. A slight rise, less than $0.5 \mathrm{ft}$, was observed in BWSD \#2, $\# 3$, and \#5. The water level in BWSD \#4 rose by about $2 \mathrm{ft}$ during a 3-week period beginning in late May 2019 and

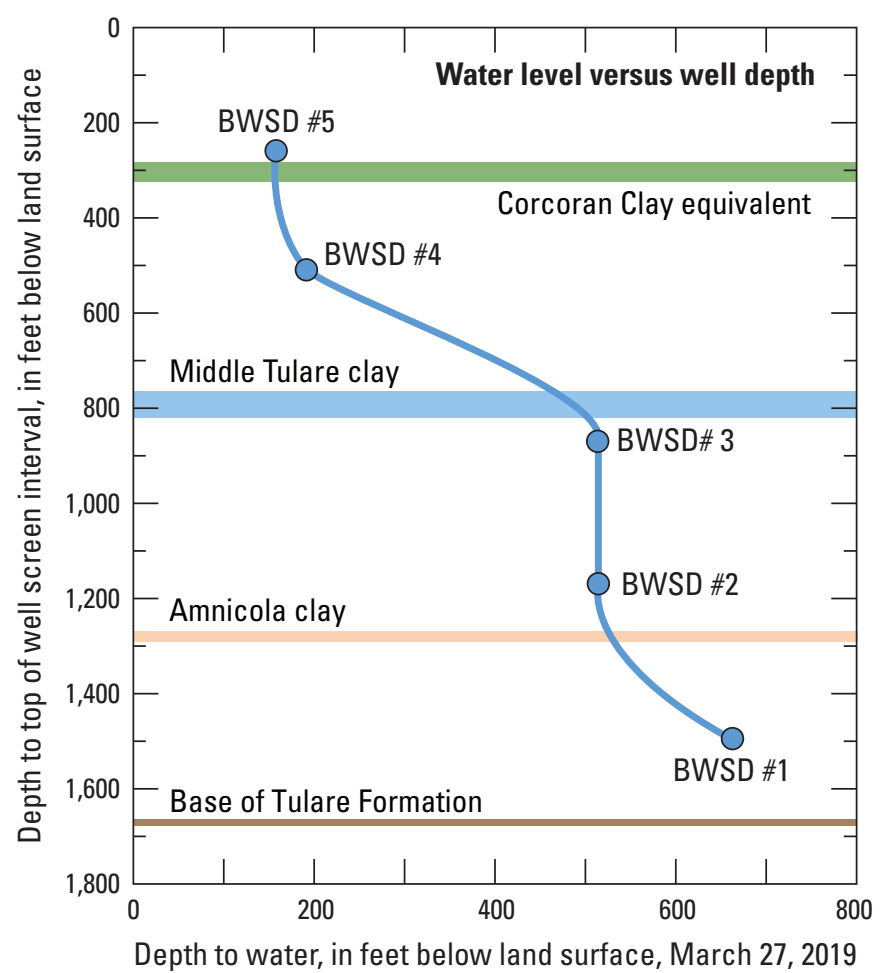

Figure 3. Vertical flow gradient at the Belridge multiple-well monitoring site (BWSD), Kern County, California. 


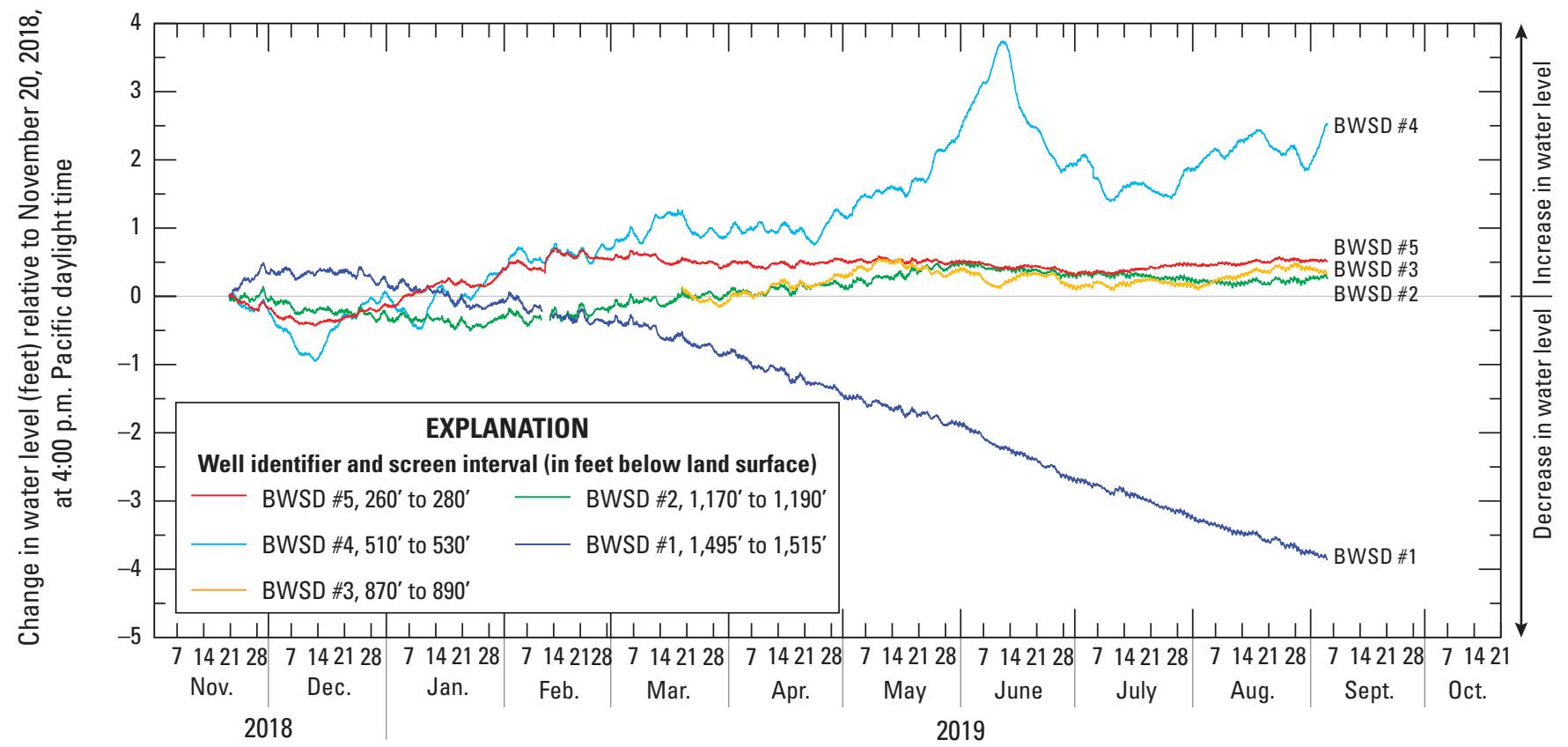

Figure 4. Change in water level relative to November 20, 2018, observed in wells at the Belridge multiple-well monitoring site (BWSD), Kern County, California.

then declined by about $2 \mathrm{ft}$ during the next 2 weeks. The exact cause of this short-term fluctuation in water level is not known. Water levels typically recover in the winter in correlation with decreased withdrawal and increased recharge from precipitation, and they decline in the summer due to increased water use and groundwater withdrawal. No corresponding rise in water level was observed in the overlying BSWD \#5; therefore, recharge from precipitation does not seem to be the likely cause for the rise in water level observed in BWSD \#4. The fluctuations in water level in BWSD \#4 over the short term (less than 7 days) were greater than those observed in the other wells, indicating that the layer in the upper part of the Tulare Formation is more strongly affected by groundwater pumping than the middle part of the Tulare Formation. The pattern of decreased water levels observed in well BWSD \#1 over time differed from the observations of the other wells (BWSD \#2-5), indicating that water levels at the bottom of the Tulare Formation are responding to different hydrologic stresses than the overlying layers. These stresses may include upgradient oil-field activities (injection, steam or water flooding, or pumping) to the southwest or other unknown deep aquifer stresses. The short-term fluctuations of less than 0.25 foot in water level, primarily observed between November 2018 and March 2019, could be indicative of upgradient pumping or injection activity or that the well is in a relatively low permeability layer that is highly responsive to changes in aquifer conditions. Further analysis of water levels over time in comparison with oil-field activities, such as pumping and injection, could be used to help determine the hydrologic stresses affecting water levels at the base of the Tulare aquifer system.

\section{Geochemistry}

To delineate the chemical characteristics and source of the groundwater, samples were collected from each well in accordance with the protocols established by the USGS National Field Manual (U.S. Geological Survey, 2012) and analyzed for major-ion chemistry; minor and trace elements; nutrients; radium isotopes; dissolved organic carbon and organic carbon characteristics; volatile organic compounds; low molecular weight organic acids; concentrations and isotopic values of light hydrocarbon gases; the stable isotopes of hydrogen (deuterium) and oxygen (oxygen-18) in water; boron, strontium, and lithium isotopes; carbon (carbon-13) in dissolved inorganic carbon and carbon-14 activities, noble gases, atmospheric gases, and groundwater-age tracers tritium and sulfur hexafluoride. The collection and analysis procedures are further described by Dillon and others (2016), Davis and others (2018b), and Wright and others (2019). Sampling of the five monitoring wells occurred between late November 2018 and mid-March 2019, with delays related to weather, site access, and equipment. Results for many analytes were not available at the time this report was prepared (September 2019). Consequently, results of water-quality samples are not discussed in this report other than the distribution of total dissolved solids (TDS). 
The permeable zones above $1,190 \mathrm{ft}$ bls (BWSD \#2), slightly above the Amnicola clay, had TDS concentrations of less than 10,000 milligrams per liter $(\mathrm{mg} / \mathrm{L})$. The water samples from the BWSD wells had TDS concentrations ranging from 2,340 (BWSD \#4) to 21,100 (BWSD \#1) mg/L residue on evaporation at 180 degrees Celsius (table 4). Total dissolved solids were calculated at multiple depths from the geophysical logs using the algorithm developed by Bateman and Konen (1977; fig. 5) and following procedures outlined by Gillespie and others $(2019 a, b)$. Total dissolved solids were not calculated between 700 and 1,200 ft bls because of the absence of clean sands throughout this interval. Total dissolved solids measured from groundwater samples collected from the wells confirmed that the calculated estimates from the geophysical logs are reasonable. Total dissolved solids calculations at selected depths shown on figure 5 indicate that TDS values were around 3,000 mg/L near the surface and exceeded $10,000 \mathrm{mg} / \mathrm{L}$ below 1,200 ft. A best-fit line for the TDS estimates between 1,200 and 1,420 ft suggested the depth to $10,000 \mathrm{mg} / \mathrm{L}$ was around 1,190 ft bls.

\section{Accessing Data}

The data presented in this report can be accessed using the USGS National Water Information System (NWIS) web interface (NWISWeb) at https://waterdata.usgs.gov/nwis/ (U.S. Geological Survey, 2019a). All discrete water-level measurements and the daily maximum, minimum, and median values for all time-series water-level data for sites presented in this report are available through the USGS NWISWeb. In digital copies of this report, the site identification numbers (table 1) presented in the tables are hyperlinked directly to the data on NWISWeb. Any updates applied to data presented in this report after publication will be available on NWISWeb.
Geophysical logs can be accessed through the USGS GeoLog Locator portal (https://webapps.usgs.gov/ GeoLogLocator; U.S. Geological Survey, 2019 b) under the site identification number for the deepest monitoring well BWSD \#1 (353049119434101). Sites with available geophysical logs can be searched by the USGS site identification number (table 1) or can be located using the interactive map. Lithologic samples collected using different methods (termed shaker and sieve, Everett and others, 2013) during the drilling of the multiple-completion monitoring wells are archived at the USGS office in San Diego, California. Photos of the shaker and sieve samples (along with the full descriptions and notes recorded by the site hydrologist) can be accessed through the USGS GeoLog Locator. Formal requests for access to samples, field notes, or bench notes can be directed to the U.S. Geological Survey California Water Science Center.

Table 4. Water-quality indicators (field parameters) and total dissolved solids in samples collected from the Belridge multiple-well monitoring site (BWSD), Kern County, California.

[Wells ordered from shallowest to deepest. The five-digit U.S. Geological Survey (USGS) parameter code below the constituent name is used to uniquely identify a specific constituent or property. Threshold type: SMCL-CA, California Department of Public Health secondary maximum contaminant level; SMCL-US, U.S. Environmental Protection Agency secondary maximum contaminant level. Abbreviations: mm/dd/yyyy, month/day/year; $\mathrm{mg} / \mathrm{L}$, milligrams per liter; ${ }^{\circ} \mathrm{C}$, degrees Celsius; $\mu \mathrm{S} / \mathrm{cm}$, microsiemens per centimeter; $\mathrm{CaCO}_{3}$, calcium carbonate; na, not available; *, value above threshold level]

\begin{tabular}{|c|c|c|c|c|c|c|}
\hline $\begin{array}{c}\text { Common well } \\
\text { name }\end{array}$ & $\begin{array}{l}\text { Sample date } \\
\text { (mm/dd/yyyy) }\end{array}$ & $\begin{array}{c}\text { pH, field } \\
\text { (standard } \\
\text { units) } \\
(00400)\end{array}$ & $\begin{array}{c}\text { Water } \\
\text { temperture, } \\
\text { field } \\
\left({ }^{\circ} \mathrm{C}\right) \\
(00010)\end{array}$ & $\begin{array}{c}\text { Specific } \\
\text { conductance, } \\
\text { field } \\
\left(\mu \mathrm{S} / \mathrm{cm} \text { at } 25^{\circ} \mathrm{C}\right) \\
(00095)\end{array}$ & $\begin{array}{c}\text { Alkalinity, lab } \\
\left.\text { (mg/L as } \mathrm{CaCO}_{3}\right) \\
(29801)\end{array}$ & $\begin{array}{c}\text { Total } \\
\text { dissolved } \\
\text { solids } \\
\text { (mg/L) } \\
(70300)\end{array}$ \\
\hline Threshold type & na & SMCL-US & na & SMCL-CA & na & SMCL-US \\
\hline Threshold level & na & $6.5-8.5$ & na & ${ }^{1} 900(1,600)$ & na & 500 \\
\hline BWSD \#5 & $02 / 11 / 2019$ & 7.3 & 26.5 & $* 3,650$ & 184 & $* 3,120$ \\
\hline BWSD \#4 & $11 / 28 / 2018$ & 7.3 & 23.5 & $* 3,460$ & 318 & $* 2,340$ \\
\hline BWSD \#3 & 03/19/2019 & 7.2 & 27.0 & $* 7,270$ & 208 & $* 4,950$ \\
\hline BWSD \#2 & $02 / 11 / 2019$ & 7.5 & 25.4 & $* 15,500$ & 323 & $* 9,420$ \\
\hline BWSD \#1 & $02 / 13 / 2019$ & 6.9 & 24.6 & $* 33,000$ & 397 & $* 21,100$ \\
\hline
\end{tabular}

${ }^{1}$ The SMCL-CA for specific conductance has recommended lower and upper threshold values. The upper value is shown in parentheses. 


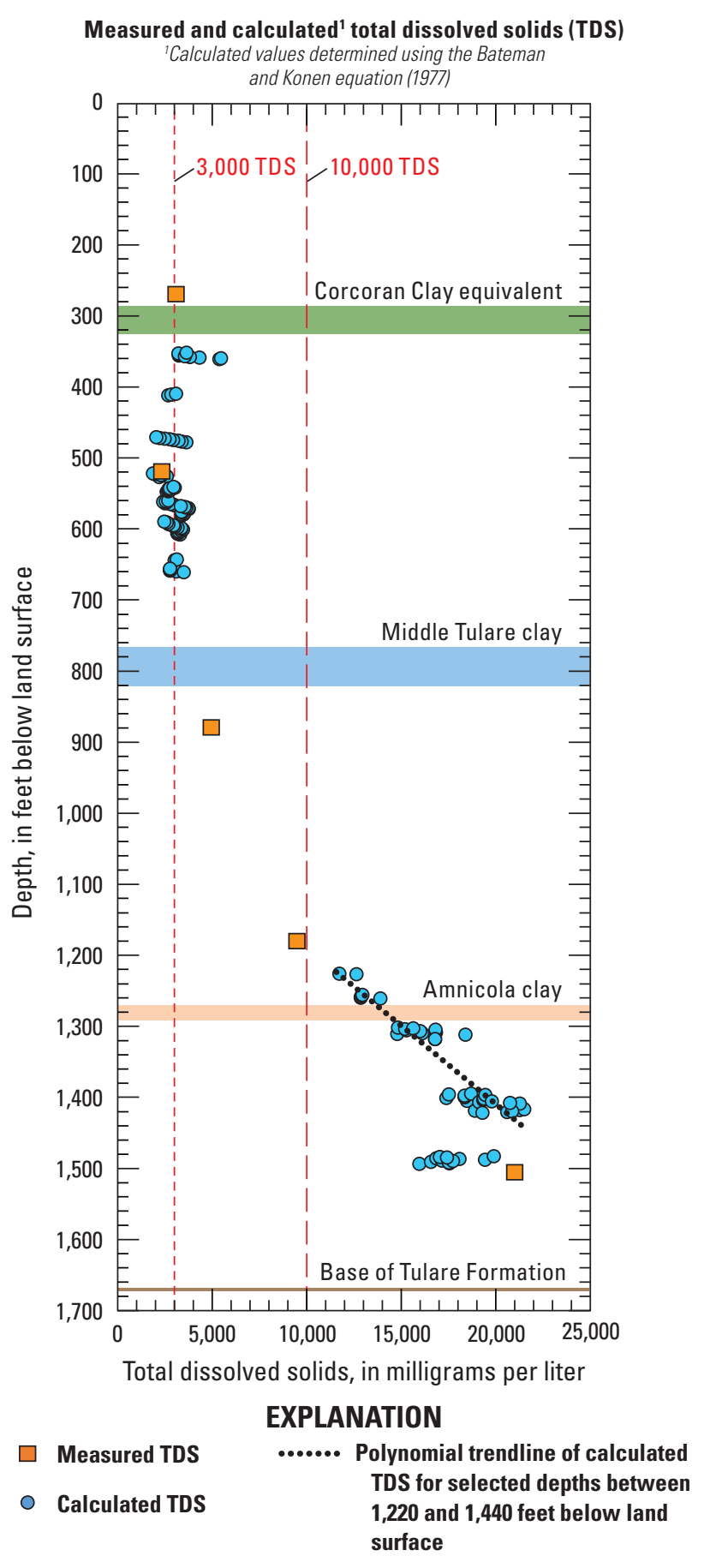

Figure 5. Measured and calculated total dissolved solids (TDS) for selected depths at the Belridge multiple-well monitoring site (BWSD), Kern County, California.

\section{By Rhett R. Everett, Anthony A. Brown, Janice M. Gillespie, Adam Kjos, and Nicole C. Fenton}

\section{References Cited}

Bateman, R.M., and Konen, C.E., 1977, The log analyst and the programmable pocket calculator: Society of Petrophysicists and Well Log Analysts, v. 18, no. 5, p. 3-10.

Butler, J.J., Jr., and Zhan, X., 2004, Hydraulic tests in highly permeable aquifers: Water Resources Research, v. 40, no. 12, 12 p., https://doi.org/10.1029/2003WR002998.

California Department of Conservation, 2018, Oil and gas online data: Geologic Energy Management Division (CalGEM), accessed February 20, 2018, at https:/www.conservation.ca.gov/calgem/ Online_Data/Pages/Index.aspx.

California Department of Water Resources, 2015, California's groundwater update 2013-A compilation of enhanced content for California water plan: California Department of Water Resources, accessed November 26, 2018, at https:/water.ca.gov/Programs/ California-Water-Plan/Previous-Updates.

California Department of Water Resources, 2016, California's groundwater bulletin 118 Interim Update 2016: California Department of Water Resources, accessed September 26, 2018, at https://water.ca.gov/Programs/Groundwater-Management/ Bulletin-118.

California State Water Resources Control Board, 2018, Geotracker advanced search, oil and gas monitoring, produced water ponds: California State Water Resources Control Board, accessed October 12, 2018, at https://geotracker.waterboards.ca.gov/search.

Croft, M.G., 1972, Subsurface geology of the late tertiary and quaternary water-bearing deposits of the southern part of the San Joaquin Valley, California: U.S. Geological Survey Water Supply Paper 1999-H, 29 p., https://doi.org/10.3133/wsp1999H.

Cunningham, W.L., and Schalk, C.W., comps., 2011, Groundwater technical procedures of the U.S. Geological Survey: U.S. Geological Survey Techniques and Methods 1-A1, 154 p., https://doi.org/10.3133/tm1A1.

Davis, T.A., Landon, M.K., and Bennett, G.L., 2018a, Prioritization of oil and gas fields for regional groundwater monitoring based on a preliminary assessment of petroleum resource development and proximity to California's groundwater resources: U.S. Geological Survey Scientific Investigations Report 2018-5065, 115 p., https://doi.org/10.3133/sir20185065.

Davis, T.A., Teunis, J.A., McCarlson, A.J., Seitz, N.O., and Johnson, J.C., 2018b, Water chemistry data for samples collected at groundwater and surface-water sites near the Lost Hills and Belridge oil fields, November 2016-September 2017, Kern County, California: U.S. Geological Survey data release, https://doi.org/10.5066/F7NS0T5M.

Dillon, D.B., Davis, T.A., Landon, M.K., Land, M.T., Wright, M.T., and Kulongoski, J.T., 2016, Data from exploratory sampling of groundwater in selected oil and gas areas of coastal Los Angeles County and Kern and Kings Counties in southern San Joaquin Valley, 2014-15-California oil, gas, and groundwater project: U.S. Geological Survey Open-File Report 2016-1181, 24 p., https://doi.org/10.3133/ofr20161181. 
Duffield, G.M., 2007, AQTESOLV for Windows version 4.5 user's guide: Reston, Virginia, HydroSOLVE, Inc., 529 p., https://hwbdocuments.env.nm.gov/Los\%20Alamos\%20National\%20Labs/General/37764.pdf.

Everett, R.R., Gibbs, D.R., Hanson, R.T., Sweetkind, D.S., Brandt, J.T., Falk, S.E., and Harich, C.R., 2013, Geology, water-quality, hydrology, and geomechanics of the Cuyama Valley groundwater basin, California, 2008-12: U.S. Geological Survey Scientific Investigations Report 2013-5108, 62 p., https://doi.org/10.3133/sir20135108.

Everett, R.R., Kjos, A., Brown, A.A., Gillespie, J.M., and McMahon, P.B., 2020a, Multiple-well monitoring site adjacent to the Lost Hills oil field, Kern County, California: U.S. Geological Survey Open-File Report 2019-1114, 8 p., https://doi.org/10.3133/ofr20191114.

Everett, R.R., Ledbetter, B.J., Rodriguez, O., and Bobbitt, M., 2020b, Aquifer test data for the Belridge multiple-well monitoring site (BWSD), Kern County, California: U.S. Geological Survey data release, https://doi.org/10.5066/P96WITX5.

Faunt, C.C., ed., 2009, Groundwater availability of the Central Valley Aquifer, California, U.S. Geological Survey Professional Paper 1766, 225 p., https://doi.org/10.3133/pp1766.

Frink, J.W., and Kues, H.A., 1954, Corcoran clay-A Pleistocene lacustrine deposit in San Joaquin Valley, California: American Association of Petroleum Geologists, v. 38, no. 11, p. 2357-2371, https://doi.org/10.1306/5CEAE0A0-16BB-11D7-8645000102C1865D.

Gillespie, J.M., Davis, T.A., Stephens, M.J., Ball, L.B., and Landon, M.K., 2019a, Groundwater salinity and the effects of produced water disposal in the Lost Hills-Belridge oilfields, Kern County, California: AAPG Environmental Geosciences, v. 26, no. 3, p. 73-96, https://doi.org/10.1306/eg.02271918009.

Gillespie, J.M., Davis, T.A., Ball, L.B., Herrera, P.J., Wolpe, Z., Medrano, V., Bobbitt, M., and Stephens, M.J., 2019b, Geological, geochemical, and geophysical data from the Lost Hills and Belridge oil fields: U.S. Geological Survey data release, https://doi.org/10.5066/P90QH6CI.

Greene, E.A., and Shapiro, A.M., 1995, Methods of conducting air-pressurized slug tests and computation of type curves for estimating transmissivity and storativity: U.S. Geological Survey Open-File Report 95-424, 43 p., https://doi.org/10.3133/ofr95424.

Heath, R.C., 1983, Basic ground-water hydrology: U.S. Geological Survey Water Supply Paper 2220, 86 p., https://doi.org/10.3133/wsp2220.

Hyder, Z., Butler, J.J., Jr., McElwee, C.D., and Liu, W., 1994, Slug tests in partially penetrating wells: Water Resources Research, v. 30, no. 11, p. 2945-2957, https://doi.org/10.1029/94WR01670.

Kenyon, B., Kleinberg, R., Straley, C., Gubelin, G., and Morriss, C., 1995, Nuclear magnetic resonance imaging-Technology for the 21st Century: Oilfield Review, v. 7, p. 19-30.

Keys, W.S., 1990, Borehole geophysics applied to ground-water investigations: U.S. Geological Survey Techniques of Water-Resources Investigations, book 2, chap. E2, 150 p., https://doi.org/10.3133/twri02E2.

Keys, W.S., and MacCary, L.M., 1971, Application of borehole physics to water-resources investigations: U.S. Geological Survey Techniques of Water-Resources Investigations, book 2, chap. E1, 126 p., https://doi.org/10.3133/twri02E1.

Leap, D.I., 1984, A simple pneumatic device and technique for performing rising water level slug tests: Ground Water Monitoring and Remediation, v. 4, no. 4, p. 141-146, https://doi.org/10.1111/j.1745-6592.1984.tb00905.x.

Page, R.W., 1983, Geology of the Tulare Formation and other continental deposits, Kettleman City area, San Joaquin Valley, California, with a section on ground-water management considerations and use of texture maps: U.S. Geological Survey Water-Resources Investigations Report 83-4000, 28 p., https://doi.org/10.3133/wri834000.

Shuter, E., and Teasdale, W.E., 1989, Application of drilling, coring, and sampling techniques to test holes and wells: U.S. Geological Survey Techniques of Water-Resources Investigations, book 2, chap. F1, 97 p., https://doi.org/10.3133/twri02F1.

Sneed, M., 2001, Hydraulic and mechanical properties affecting ground-water flow and aquifer-system compaction, San Joaquin Valley, California: U.S. Geological Survey Open-File Report 2001-35, 26 p., https://doi.org/10.3133/ofr0135.

Swanson, R.G., 1981, Sample examination manual: Tulsa, Oklahoma, American Association of Petroleum Geologists, 54 p., https://doi.org/10.1306/Mth1413.

U.S. Geological Survey, 2012, The national field manual for the collection of water-quality data (version 7): U.S. Geological Survey Techniques and Methods, book 9, chaps. A1-A9, accessed April 5, 2013, at https://water.usgs.gov/owq/FieldManual/. 
U.S. Geological Survey, 2017, California oil, gas, and groundwater (COGG) program: U.S. Geological Survey, accessed July 8, 2019, at https://ca.water.usgs.gov/projects/oil-gas-groundwater/index.html.

U.S. Geological Survey, 2019a, National Water Information System: U.S. Geological Survey web interface, https://doi.org/10.5066/F7P55KJN.

U.S. Geological Survey, 2019b, USGS Geolog Locator: U.S. Geological Survey web interface, https://doi.org/10.5066/F7X63KT0.

Williamson, A.K., Prudic, D.E., and Swain, L.A., 1989, Ground-water flow in the Central Valley, California: U.S. Geological Survey Professional Paper 1401-D, 127 p., https://doi.org/10.3133/pp1401D.

Wood, P.R., and Davis, G.H., 1959, Ground-water conditions in the Avenal-McKittrick area, Kings and Kern Counties, California: U.S. Geological Survey Water Supply Paper 1457, 141 p., https://doi.org/10.3133/wsp1457.

Wright, M.T., McMahon, P.B., Landon, M.K., and Kulongoski, J.T., 2019, Groundwater quality of a public-supply aquifer in proximity to oil development, Fruitvale oil field, Bakersfield, California: Applied Geochemistry, v. 106, p. 82-95, https://doi.org/10.1016/j.apgeochem.2019.05.003.

Wyman, R.E., and Castano, J.R., 1974, Show descriptions from core, sidewall and ditch samples: Society of Petrophysicists and Well-Log Analysts, SPWLA 15th Annual Logging Symposium, June 2-5, 1974, 21 p.

For more information concerning the research in this report, contact the Director, California Water Science Center

U.S. Geological Survey

6000 J Street, Placer Hall

Sacramento, California 95819

https://ca.water.usgs.gov

Publishing support provided by the

U.S. Geological Survey Science Publishing Network,

Sacramento Publishing Service Center 